mắt hay gặp nốt sần màu vàng cam, xuất huyết, bong thanh dịch... Trên OCT thấy dấu hiệu bong biểu mô sắc tố dạng vòm, dấu hiệu hai lớp tương ứng với hình ảnh mạng mạch nhánh (BVN) trên OCTA. Hình thái của BVN có thể được phân biệt thành 3 loại, việc xác định hình thái học của BVN có tương quan với biểu hiện lâm sàng và tiên lượng ở bệnh nhân PCV. OCTA có thể phát hiện polyp và $B V N$ và độ nhạy phát hiện của nó thấp hơn đối với polyp và cao hơn đối với BVN so với phát hiện của ICGA. ICGA xâm lấn nhiều hơn có thể được dành cho các trường hợp ít hơn với OCTA âm tính nhưng nghi ngờ PCV cao.Hạn chế của việc phát hiện polyp bằng OCTA bao gồm bong biểu mô sắc tố cao và polyp nhỏ và ICGA nên được thực hiện để xác định chẩn đoán trong các trường hợp nghi ngờ PCV trên lâm sàng.

\section{TÀI LIÊU THAM KHẢO}

1. Ciardella AP, Donsoff IM, Huang SJ, Costa DL, Yannuzzi LA. Polypoidal choroidal vasculopathy. Survey of ophthalmology. 2004; 49(1):25-37.

2. Cackett $P$, Wong $D$, Yeo I. A classification system for polypoidal choroidal vasculopathy. Retina. 2009;29(2):187-191.

3. Seong S, Choo HG, Kim YJ, et al. Novel Findings of Polypoidal Choroidal Vasculopathy via Optical Coherence Tomography Angiography. Korean journal of ophthalmology : KJO. 2019;33(1):54-62.

4. Kawamura A, Yuzawa M, Mori R, Haruyama M, Tanaka K. Indocyanine green angiographic and optical coherence tomographic findings support classification of polypoidal choroidal vasculopathy into two types. Acta ophthalmologica. 2013;91(6):e474-481.

5. Tomiyasu T, Nozaki M, Yoshida M, Ogura Y. Characteristics of Polypoidal Choroidal Vasculopathy Evaluated by Optical Coherence Tomography Angiography. Investigative ophthalmology \& visual science. 2016;57(9):OCT324-330.

6. Chaikitmongkol V, Cheung CMG, Koizumi H, Govindahar V, Chhablani J, Lai TYY. Latest Developments in Polypoidal Choroidal Vasculopathy: Epidemiology, Etiology, Diagnosis, and Treatment. Asia-Pacific journal of ophthalmology (Philadelphia, Pa.). 2020;9(3):260-268.

7. Hwang DK, Yang CS, Lee FL, Hsu WM. Idiopathic polypoidal choroidal vasculopathy. Journal of the Chinese Medical Association : JCMA. 2007;70(2):84-88.

\title{
KẾT QUẢ ĐIÎ̀U TRI BỔ TRỢ TRƯớC PHÁC Đồ HÓA CHẤT KẾT HỢP TRASTUZUMAB VÀ PERTUZUMAB TRÊN UNG THƯ VÚ CÓ HER2-NEU DƯO'NG TÍNH
}

\section{TÓM TẮT}

Điều trị hóa chất kết hợp các thuốc kháng HER2neu đã trở thành tiêu chuẩn trong điều trị ung thư vú có HER2-neu dương tính trên thế giới. Tại Việt Nam, Trastuzumab được sử dụng từ năm 2006 còn Pertuzumab mới được đưa vào sử dung gân đây. Nghiên cứu mô tả hồi cứu kết hợp tiến cứu đánh giá kết quả điều tri bổ trơ trước phác đồ hóa chất kết hợp Trastuzumab và Pertuzumab trên bệnh nhân ung thư vú có HER2-neu dương tính tại bênh viên $\mathrm{K}$ từ 1/2018 đến 4/2021. Kết quả nghiên cứu trên 20 bệnh nhân cho thấy tỉ lệ đáp ứng toànbộ trên lâm sàng đạt 95,0\%, có một trường hợp bệnh tiến triển. Đáp ứng mô hoc hoàn toàn toàn bô cá u và hach (tpCR) đat $80,0 \%$. Không có mối liên quan giữa tỷ lệ tpCR và các yếu tố tuổi, giai đoan u, giai đoạn hạch, type mô bệnh học, độ mô học, tình trạng nội tiết, Ki67 và phác đồ hóa chất. Phác đồ dung nạp tốt, không có trướng hợp nào trì hoãn hoặc dừng điểu trị do độc tính.

Tư khóa: hóa chất bổ trợ trước, pertuzumab, ung thư vú HER2-neu dương tính

*Bênh viên K

Chịu trách nhiệm chính: PhùngThị Huyền

Email: phungthihuyen@gmail.com

Ngày nhân bài: 10.9.2021

Ngày phản biên khoa hoc: 1.11.2021

Ngày duyệt bài: 12.11.2021
Phùng Thị Huyền*

\section{SUMMARY}

EFFICACY OF NEOADJUVANT THERAPY WITH

CHEMOTHERAPY COMBINED WITH TRASTUZUMAB AND PERTUZUMAB IN PATIENTS WITH HER2-NEU POSITIVE BREAST CANCER

HER2-neu targeted therapy in combination with chemotherapy has been the standard treatment for HER2-neu positive cancer in the world. In Vietnam, Trastuzumab has been used since 2016 while Pertuzumab has just recently been used. This is a descriptive cohort study evaluating the efficacy of neoadjuvant Trastuzumab and Pertuzumab in combination with chemotherapy for HER2-neu positive breast cancer at K hospital from 01/2018 to 04/2021. The results on 20 patients showed that the clinical overall response rate was $95.0 \%$, with only one patient progressed. Total pathological complete response (tpCR) rate was $80.0 \%$. There were no associations between tpCR and age, tumor and nodal stage, histological type and grade, ER, PR, Ki67 status and chemotherapy regimen. The regimens were well tolerated and no patients had treatment delay or interruption due to toxicities.

Keywords: neoadjuvant, Pertuzumab, HER2-neu positive breast cancer

\section{I. ĐĂT VẤN ĐỀ}

Ung thư vú là bệnh ung thư có tỉ lệ mắc cao 
nhất và cũng là nguyên nhân gây tử vong hàng đầu do ung thư ở nữ trên thế giới cũng như ở Việt Nam. ${ }^{1}$ Trong đó, nhóm ung thư vú có HER2neu dương tính thường tiên lượng xấu, tiến triển nhanh và tái phát sớm. ${ }^{2}$ Sự ra đời các nhóm thuốc kháng HER2-neu đã làm thay đổi ngoạn mục kết quả điều trị ở phân nhóm bệnh nhẩn này. Hiện nay trong nhiêu hướng dẫn điều trị quốc tế, hóa chất kết hợp với các nhóm thuốc kháng HER2-neu đã trở thành điều trị tiêu chuẩn cho ung thư vú có HER2-neu dương tính. ${ }^{3}$ Tại Việt Nam, nếu như Trastuzumab được áp dụng trong điều trị ung thư vú HER2-neu dương tính từ năm 2006 thì Pertuzumab mới chỉ được đưa vào điều trị trong những năm gần đây. Do gánh nặng về chi phí kinh tế cũng như nguồn cung cấp thuốc chỉ hạn chế ở một số trung tâm ung bướu nên số lượng bệnh nhân ung thư vú có HER2-neu dương tính được điều trị bằng phác đồ hóa chất kết hợp với Pertuzumab và Trastuzumab không nhiều. Hiện tại chưa có nghiên cứu nào tại Việt Nam đánh giá về hiệu quả điều trị phác đồ hóa chất kết hợp với Pertuzumab và Trastuzumab, do đó chúng tôi thực hiện đề tài "Kết quả điều trị bổ trợ trước bằng phác đồ hóa chất kêt hợp Trastuzumab và Pertuzumab trên bệnh nhân ung thư vú HER2neu dương tính".

\section{II. ĐỐI TƯợNG VÀ PHƯƠNG PHÁP NGHIÊN CỨU}

1. Đối tượng nghiên cứu. Gồm 20 bệnh nhân ung thư vú được điều trị bổ trợ trước phác đồ hóa chất kết hợp Pertuzumab và Trastuzumab tại bệnh viện $K$ từ tháng $1 / 2018$ đến tháng 4/2021.

\section{Tiêu chuân lứa chọn:}

- Bệnh nhân nữ được chẩn đoán xác định ung thư biểu mồ tuyến vú bằng xét nghiệm mô bệnh học.

- Các bệnh nhân có chỉ định điều trị bổ trợ trước:

+ Ung thư vú thể viêm

+ Người bệnh có chống chỉ định phẫu thuật tại thời điểm chẩn đoán

+ Bệnh nhân có kế hoạch phẫu thuật bảo tồn hay phẩu thuật thẩm mỹ tuyến vú sau điều trị bổ trợ trước

+ Bệnh nhân giai đoạn tiến triển tại chỗ T3N1 hoặc T4 hoặc N2, N3 không có khả năng phẫu thuật ở thời điểm hiện tại

+ Bệnh nhân có HER2-neu dương tính và cT2 hoặc N1 trở lên

+ Khối u ở vị trí không thuận lợi cho việc phẫu thuật ngay từ đầu: u cạnh xương ức, u 1/4 trên ngoài sát nách...

- Có thông tin về ER, PR, HER2-neu được xác định bằng $\mathrm{IHC}(+++)$ hoặc FISH $(+)$ của tổn thương u ban đầu

- Bệnh nhân được điều trị hóa chấtbổ trợ trướcphối hợp Trastuzumab vàPertuzumabítnhất 3 chu kì.

- Có kết quả mô bệnh học sau phẫu thuật

- Chức năng tống máu thất trái trước điều trị (left ventricular ejection fraction - LVEF ) $\geq 55 \%$

- Chức năng gan thận tủy xương tim trong giới hạn cho phép điều trị hóa chất

\section{Tiêu chuân loai trứ:}

- Bệnhnhâncó di cănxa

- Có tiền sử di ứng với các thuốc trong phác đồ điều trị

- Bệnh nhân bỏ điều trị không phả ivì lý do chuyênmôn

- Không điều trị đầy đủ cả 2 thuốc kháng HER2-neu

- Hồ sơ thiếu thông tin nghiên cứu

\section{Phương pháp nghiên cứu}

- Nghiên cứu mô tả hồi cứu kết hợp tiến cứu, chọn mẫu thuận tiện.

- Các phác đồ được sử dụng trong nghiên cứu:

- AC-THP: Doxorubicin liều $60 \mathrm{mg} / \mathrm{m}^{2}$, Cyclophosphamide $600 \mathrm{mg} / \mathrm{m}^{2}$, truyền mỗi 2 tuần hoặc 3 tuần. Sau đó truyền Trastuzumab $8 \mathrm{mg} / \mathrm{kg}$ chu kì 1 và $6 \mathrm{mg} / \mathrm{kg}$ từ chu kì 2 , Pertuzumab 840 $\mathrm{mg}$ chu kì 1 và $420 \mathrm{mg}$ từ chu kì 2 , Docetaxel $75-100 \mathrm{mg} / \mathrm{m}^{2}$ mỗi 3 tuần hoặc Paclitaxel 80 $\mathrm{mg} / \mathrm{m}^{2}$ ngày $1,8,15$ chu kì 3 tuần.

- TCHP: Docetaxel $75 \mathrm{mg} / \mathrm{m}^{2}$, Carboplatin AUC 6 , Trastuzumab $8 \mathrm{mg} / \mathrm{kg}$ chu kì 1 và 6 $\mathrm{mg} / \mathrm{kg}$ từ chu kì 2, Pertuzumab $840 \mathrm{mg}$ chu kì 1 và $420 \mathrm{mg}$ từ chu kì 2 , truyền mỗi 3 tuần.

- Bệnh nhân được sử dụng thuốc tang bạch cầu dự phòng nếu có chỉ định.

- Các bước tiến hành

-Thu thập thông tin đặc điểm đối tượng nghiên cứu, kết quả điều trị

- Đánh giá đáp ứng lâm sàng khối u, hạch, đáp ứng chung theo tiêu chuẩn RECIST 1.1 chia thành 4 mức độ đáp ứng: đáp ứng hoàn toàn (CR), đáp ứng một phần (PR), giữ nguyên (SD), bệnh tiến triển (PD)sau 3-4 chu kì.

- Đánh giá đáp ứng mô bệnh học tại khối u, hạch, cả u và hạch theo phân loại Chevallier. Tứ phân loại của Chevallier, chúng tôi chia thành 2 nhóm đáp ứng hoàn toàn mô bệnh học $(\mathrm{pCR})$ và không đáp ứng hoàn toàn mô bệnh học (no pCR) đối với mỗi đánh giá của u và hạch. Trường hợp đáp ứng mô học hoàn toàn toàn bộ cả u và hạch được gọi là tpCR (total pathologic complete response).

- Độc tính được ghi nhận trong thời gian điêu 
trị và phân loại theo CTCAE 5.0

3. Xử lý số liệu. Sử dụng phần mềm thống kê SPSS 16

Các thuật toán thống kê:

- Mô tả: Trung bình, độ lệch chuẩn, giá trị $\max , \min$.

- Kiểm đinh so sánh:

Đối với biến định tính: Sử dụng test so sánh $\chi^{2}$, các so sánh có ý nghĩa thống kề với $p<0,05$. Trong trường hợp mẩu nhỏ hơn 5 thì sử dụng test $\chi^{2}$ có hiệu chỉnh Fisher.

T-student để so sánh trung bình $(p<0,05)$.

4. Đạo đức nghiên cứu. Các phác đồ trong nghiên cứu có trong hướng dẫn chẩn đoán và điều trị của Bộ $Y$ tế. Nghiên cứu này nhằm mục đích nẩng cao chất lượng điều trị cho bệnh nhẩn ngoài ra không nhằm mục đích nào khác.

\section{KẾT QUẢ NGHIÊN CỨU}

1. Đặc điểm bệnh nhânnghiêncứu

Bảng 1: Đặc điểm đôii tượng nghiên cứu

\begin{tabular}{|c|c|c|}
\hline Đặc điểm & $\begin{array}{c}\text { Số bệnh } \\
\text { nhân (N=20) }\end{array}$ & $\begin{array}{c}\text { Tỷ lệ } \\
\text { \%o }\end{array}$ \\
\hline Tuối: $<40$ & 7 & $35 \%$ \\
\hline $40-60$ & 11 & $55 \%$ \\
\hline$\geq 60$ & 2 & $10 \%$ \\
\hline Trung bình & $46,3 \pm 9,7$ \\
\hline
\end{tabular}

Tình trạng kinh nguyệt

\begin{tabular}{|c|c|c|}
\hline Còn kinh nguyệt & 15 & $75 \%$ \\
\hline Mãn kinh & 5 & $25 \%$ \\
\hline Vị trí vú: Vú trái & 12 & $60 \%$ \\
\hline Vú phái & 7 & $35 \%$ \\
\hline Hai vú & 1 & $5 \%$ \\
\hline
\end{tabular}

Vị trí u

\begin{tabular}{|c|c|c|}
\hline $1 / 4$ trên ngoài & 13 & $65 \%$ \\
\hline $1 / 4$ trên trong & 3 & $15 \%$ \\
\hline Trung tâm & 2 & $10 \%$ \\
\hline $1 / 4$ dưới ngoài & 1 & $5 \%$ \\
\hline $1 / 4$ dưới trong & 1 & $5 \%$ \\
\hline Giai đoạn khối u: cT1 & 3 & $15 \%$ \\
\hline cT2 & 9 & $45 \%$ \\
\hline cT3 & 6 & $30 \%$ \\
\hline cT4 & 2 & $10 \%$ \\
\hline
\end{tabular}

$\begin{gathered}\text { Kích thước u trung bình } \\ (\mathrm{cm})\end{gathered} \quad 4,4 \pm 2,2$

\begin{tabular}{|c|c|c|}
\hline Giai đoạn hạch: cN0 & 2 & $10 \%$ \\
\hline cN1 & 2 & $10 \%$ \\
\hline cN2 & 16 & $80 \%$ \\
\hline Giai đoạn: IIB & 4 & $20 \%$ \\
\hline IIIA & 14 & $70 \%$ \\
\hline IIIB & 2 & $10 \%$ \\
\hline Mô bệnh học: NST & 20 & $100 \%$ \\
\hline Thế khác & 0 & 0 \\
\hline Độ mô học: 2 & 16 & $80 \%$ \\
\hline 3 & 4 & $20 \%$ \\
\hline Type pân tữ & \multicolumn{2}{|c|}{} \\
\hline
\end{tabular}

\begin{tabular}{|c|c|c|}
\hline Bộc lộ quá mức HER2-neu & 11 & $55 \%$ \\
\hline Lumial B HER2-neu(+) & 9 & $45 \%$ \\
\hline Ki67: $<20 \%$ & 1 & $5 \%$ \\
\hline$\geq 20 \%$ & 19 & $95 \%$ \\
\hline \multicolumn{3}{|l|}{ Phác đồ hóa chất } \\
\hline AC-THP & 11 & $55 \%$ \\
\hline TCHP & 9 & $45 \%$ \\
\hline
\end{tabular}

Trong khoảng thời gian từ tháng 1/2018 đến tháng 4/2021, 20 bệnh nhân ung thư vú giai đoạn từ IIB-IIIC có HER2-neu dương tính được điêuu trị bổ trợ trước hóa chất kết hợp Trastuzumab và Pertuzumab tại bệnh viện $K$. Đặc điểm bệnh nhân nghiên cứu được trình bày ở Bảng 1 .

2. Hiệu quả của phác đồ bổ trợ trước hóa chất kêt hợp Trastuzumab và Pertuzumab

Bảng 2: Tỉ lệ đáp ứng lâm sàng và mô học

\begin{tabular}{|c|c|c|c|}
\hline \multicolumn{2}{|c|}{$\begin{array}{l}\text { Đáp ứng lâm } \\
\text { sàng }\end{array}$} & $\begin{array}{c}\text { Số bệnh nhân } \\
(\hat{N}=20)\end{array}$ & $\begin{array}{l}\text { Tỷ lệ } \\
\%\end{array}$ \\
\hline \multirow{4}{*}{ U vú } & $\mathrm{CR}$ & 11 & $55 \%$ \\
\hline & PR & 8 & $40 \%$ \\
\hline & PD & 1 & $5 \%$ \\
\hline & Tống & 20 & $100 \%$ \\
\hline \multirow{4}{*}{ Hạch } & CR & 16 & $80 \%$ \\
\hline & PR & 3 & $15 \%$ \\
\hline & PD & 1 & $5 \%$ \\
\hline & Tống & 20 & $100 \%$ \\
\hline \multirow{4}{*}{$\begin{array}{l}\text { U và } \\
\text { hạch }\end{array}$} & CR & 11 & $55 \%$ \\
\hline & PR & 8 & $40 \%$ \\
\hline & PD & 1 & $5 \%$ \\
\hline & Tống & 20 & $100 \%$ \\
\hline \multicolumn{2}{|c|}{ Đáp ứng mô học } & $\mathbf{n}$ & $\%$ \\
\hline \multirow{3}{*}{ U vú } & $\mathrm{pCR}$ & 16 & $80 \%$ \\
\hline & no pCR & 4 & $20 \%$ \\
\hline & Tống & 20 & $100 \%$ \\
\hline \multirow{3}{*}{ Hạch } & pCR & 19 & $95 \%$ \\
\hline & no pCR & 1 & $5 \%$ \\
\hline & Tổng & 20 & $100 \%$ \\
\hline \multirow{3}{*}{$\begin{array}{l}\text { U và } \\
\text { hạch }\end{array}$} & tpCR & 16 & $80 \%$ \\
\hline & no pCR & 4 & $20 \%$ \\
\hline & Tống & 20 & $100 \%$ \\
\hline
\end{tabular}

Tỷ lệ đáp ứng mô học hoàn toàn toàn bộ (tpCR) trong nghiên cứu của chúng tôi là $80 \%$. Tỷ lệ đáp ứng mô học hoàn toàn tại u vú là $80 \%$ và tỷ lệ đáp ứng mô học hoàn toàn tại hạch đạt $95 \%$. Đánh giá đáp ứng trên lâm sàng theo RECIST 1.1, tỷ lê đáp ứng toànbô cả u và hach là 95\% (bảng 2). Có một trường hợp bệnh tiến triển sau khi kết thúc tân bổ trợ.

Bảng 3: Tỉ lệ đáp ứng mô học theo yêu tố liên quan

\begin{tabular}{|c|c|c|c|}
\hline Đặc điểm & $\begin{array}{c}\text { pCR } \\
(\mathbf{N = 1 6 )})\end{array}$ & $\begin{array}{c}\text { Không } \\
\mathbf{p C R} \\
(\mathbf{N}=4)\end{array}$ & $\mathbf{p}$ \\
\hline Tuối: $<40$ tuối & 5 & 2 & 0,364 \\
\hline
\end{tabular}




\begin{tabular}{|c|c|c|c|}
\hline $40-60$ & 10 & 1 & \\
\hline$\geq 60$ & 1 & 1 & \\
\hline \multicolumn{4}{|c|}{ Giai đoạn khối u (T) } \\
\hline $\mathrm{T} 1$ & 3 & 0 & \multirow{4}{*}{0,651} \\
\hline T2 & 7 & 2 & \\
\hline T3 & 5 & 1 & \\
\hline T4 & 1 & 1 & \\
\hline \multicolumn{4}{|c|}{ Giai đoạn hạch (N) } \\
\hline N0 & 1 & 1 & \multirow{3}{*}{0,624} \\
\hline N1 & 2 & 0 & \\
\hline N2 & 13 & 3 & \\
\hline Giai đoạn: IIB & 3 & 1 & \multirow{3}{*}{0,493} \\
\hline IIIA & 12 & 2 & \\
\hline IIIB & 1 & 1 & \\
\hline Độ mô học: 2 & 13 & 2 & \multirow{2}{*}{0,249} \\
\hline 3 & 3 & 2 & \\
\hline \multicolumn{4}{|l|}{ Type phântử } \\
\hline $\begin{array}{l}\text { Bộc lộ quá mức } \\
\text { HER2-neu }\end{array}$ & 6 & 3 & \multirow{2}{*}{0,285} \\
\hline $\begin{array}{c}\text { Lumial B HER2 } \\
\text {-neu }(+)\end{array}$ & 10 & 1 & \\
\hline Ki67: $<20 \%$ & 1 & 0 & \multirow{2}{*}{1,000} \\
\hline$\geq 20 \%$ & 15 & 4 & \\
\hline Phác đồ: AC-THP & 10 & 1 & \multirow{2}{*}{0,285} \\
\hline TCHP & 6 & 3 & \\
\hline
\end{tabular}

pCR: đáp ứng hoàn toàn trên mô bệnh học

Khi phân tích mối liên quan tình trạng đáp ứng hoàn toàn trên mô bệnh học với các yếu tố tuổi $(<40,40-60,>60)$, giai đoạn u $(T)$, giai đoạn $N$, giai đoạn chung, type mô bệnh học, độ mổ học, type phân tử, Ki67 và phác đồ hóa chất, chúng tôi nhận thấy khác biệt không có ý nghĩa thống kê khi so sánh tỷ lệ tpCR với p>0,05 (bảng 3).

\section{3. Độc tính}

Bảng 4: Độc tính trong thời gian điều trị Đốc tính mức đồ 3, 4

Hạ bạch cầu trung tính

Ha bạ̣ch cầu trung tính có sốt

Hạ tiểu câu độ

Bưồn nôn, nôn

Thay đổi creatinin Men gan (GOT/GPT)

Giảm chức năng tim phải trì

hoãn hoặc ngừng điều trị

Thời gian theo dõi còn hạn chế nên bước đầu chúng tôi ghi nhận một số độc tính thường gặp xảy ra trong thời gian điều trị. Sử dụng phân độ độc tính CTCAE để đánh giá mức độ độc tính gặp phải. Tỉ lệ người bệnh hạ bạch câu trung tính mức độ nặng (độ 3,4) là 15\%. Có 1 trường hợp hạ bạch cầu có sốt (5\%). Tỉ lệ người bệnh xuất hiện nôn buồn nôn độ 3,4 là $10 \%$. Khổng ghi nhận trường hợp nào hạ tiểu cầu, tăng men gan và tăng creatinin mức độ 3,4 . Kết quả nghiên cứu không ghi nhận trường hợp xuất hiện các biến cố liên quan đến tim mạch phải trì hoã̉n hoặc ngừng điều trị (bao gồm suy tim trên lâm sàng, giảm phân suất tống máu (LVEF) >10\%).

\section{BÀN LUẬN}

Tỷ lệ đáp ứng hoàn toàn về mô bệnh học (tpCR) thường là mục tiêu đánh giá chính của các nghiên cứu liên quan đến điều trị tân bổ trợ. Mục tiêu chính trong nghiên cứu của chúng tôi là đánh giá tỉ lệ đáp ứng hoàn toàn mô bệnh học. Đáp ứng hoàn toàn mô bệnh học liên quan đến giảm tỉ lệ tái phát và tử vong đã được chứng minh qua nhiều nghiên cứu. Các nghiên cứu gần đây cho thây hiệu quả của phác đồ bổ trợ trước hóa chất kết hợp Trastuzumab và Pertuzumab cải thiện rõ rệt tỷ lệ tpCR ở bệnh nhân ung thư vú có HER2 dương tính. Trong nghiên cứu NeoSphere, đối tượng nghiên cứu được phân thành 4 nhóm điều trị gồm Trastuzumab phối hợp Docetaxel, Pertuzumab phối hợp Trastuzumab và Docetaxel, Pertuzumab kết hợp Trastuzumab, Docetaxel kết hợp Pertuzumab. Mục tiêu chính của nghiên cứu NeoSphere là đánh giá đáp ứng toàn bộ mô bệnh học tại thời điểm bệnh nhân phẫu thuật. Kểt quả, nhóm được điều trị bổ trợ trước bằng phác đồ Docetaxel kết hợp Trastuzumab và Pertuzumab có tỷ lệ đáp ứng hoàn toàn mô bệnh học tại u vú (bpCR) là $45,8 \%$ và tỷ lệ đáp ứng hoàn toàn cả vú và hạch (tpCR) đạt $39,3 \%$, cao hơn có ý nghĩa thống kê so với các nhóm còn lại. ${ }^{4}$ Tỉ lệ đáp ứng toàn bộ mô bệnh học (tpCR) trong nghiên cứu của chúng tôi là $80 \%$ cao hơn so với nghiên cứu NeoSphere. Theo chúng tôi, hạn chế trong nghiên cứu NeoSphere là sử dụng phác đồ hóa chất chỉ một loại hóa chất là Docetaxel. Thực tế đối với bệnh nhân ung thư vú giai đoạn tiển xa tại chỗ việc sử dụng hóa chất kết hợp sẽ đem lại tỉ lệ đáp ứng cao hơn. Ở nghiên cứu của chúng tôi, phác đồ hóa chất sử dụng là ACTHP và TCHP trong đó ACTHP chiếm tî lệ $55 \%$. Đây đều là những phác đồ được nhiều hướng dẫn điều trị khuyến nghị sử dụng trong điều trị hóa chất tân bổ trợ ung thư vú hiện nay. Có thể điều này dẫn đến sự khác biệt trong kết quả nghiên cứu của chúng tôi với nghiên cứu NeoSphere. Một nghiên cứu khác, nghiên cứu TRYPHAENA cho thấy tỷ lệ tpCR dao động từ $54,7-63,6 \%$ ở các nhóm điêu trị, trong đó tî lệ đáp ứng đạt cao nhất ở nhóm sử dụng phác đồ TCHP. ${ }^{5}$ Mặc dù mục tiêu chính của nghiên cứu này không phải là đánh giá tpCRtuy nhiênở mục tiêu phụ, kết quả tpCR ở nhóm sử dụng phác đồ TCHP gần tương đồng với kết quả nghiên cứu của chúng tôi (tî lệ sử 
dụng phác đồ TCHP trong nghiên cứu của chúng tôi là $45 \%$ ). Một nghiên cứu được thực hiện bởi chúng tôi trước đây nhằm đánh giá đáp ứng điều trị bổ trợ trước phác đồ hóa chất kết hợp Trastuzumab có tỉ lệ đáp ứng tpCR đạt $56,4 \%{ }^{6}$. So sánh với kết quả của nghiên cứu này bước đầu cho thấy hiệu quả vượt trội ở nhóm được điều trị phối hợp hóa chất và Trastuzumab, Pertuzumab tuy nhiên cần những nghiên cứu với số lượng bênh nhân lớn hơn và so sánh đối đâu trực tiếp với nhóm chỉ được dùng hóa chất kết hợp Trastuzumab. Trong nghiên cứu của chúng tôi có một trường hợp tiến triển sau điều trị phác đồ AC-THP. Trường hợp này có nhiều yếu tố tiên lượng xấu như giai đoạn IIIA, carcinoma xâm nhập NST độ mô học 3, nội tiết âm tính. Bệnh nhẩn này cũng được ghi nhận đáp ứng kém với các phác đồ hóa chất sau đó.

Đã có nhiêu nghiên cứu nhằm tìm ra yếu tố dự đoán tpCR trên đối tượng nghiên cứu. Nghiên cứu TECHNO cho thấy không khác biệt tỷ lệ tpCRkhi so sánh với các yếu tố tuổi $(<40 ; \geq 40)$, type mô bệnh học, độ mô học, giai đoạn $u$, giai đoạn hạch và tình trạng nội tiết. ${ }^{7}$ Ngược lại, nghiên cứu Gepar Quattro cho thây tỷ lệ pCR cao hơn ở nhóm thụ thể nội tiết âm tính $(43,5 \%)$ trong khi nhóm thụ thể nội tiết dương tính chỉ đạt $23,4 \%$ với $p<0,001 .{ }^{8}$ Nghiên cứu NOAH ghi nhận sự khác biệt tỷ lê pCR giữa giai đoạn II $(75 \%)$ và III $(40 \%)$ với $p=0,03$. Sau khi phân tích tỷ lệ tpCR với các yếu tố tuổi $(<40 ; \geq 40)$, giai đoạn $\mathrm{u}(\mathrm{T})$, giai đoạn $\mathrm{N}$, giai đoạn chung, type mô bệnh học, độ mô học, tình trạng nội tiết, Ki67 và phác đồ hóa chất qua bảng 3 ,kết quảcủa chúng tôi cho thấy khác biệt không có ý nghĩa thống kê với $p>0,05$. Tuy nhiên do nghiên cứu của chúng tôi số lượng bệnh nhân còn hạn chế nên cần có những nghiên cứu sau với cõ mẫu lớn hơn.

Kết quả nghiên cứu của chúng tôi cho thấy phác đồ điều trị dung nạp tốt, không có trường hợp trì hoãn hoặc dừng điều trị vì lý do độc tính của thuốc. Tỉ lệ hạ bạch câuu trung tính mức độ nặng (từ độ 3 trở lên) chiếm $15 \%$. Kết quả này gần tương tự với kết quả trong nghiên cứu APHINITY (tỉ lệ hạ bạch câu trung tính độ 3, 4 là 16,3\%). ${ }^{9}$ Tác dụng phụ trên tim mạch luổn được chú trọng ở bệnh nhân điều trị phác đồ có thuốc kháng HER2. Nghiên cứu NOAH ghi nhận tỷ lệ suy tim có triệu chứng $<2 \%$ ở nhóm hóa trị bổ trợ có kết hợp Trastuzumab. Một nghiên cứu khác, nghiên cứu NeoSphere cho thấy khi kết hợp thêm Pertuzumab và Trastuzumab không làm thay đổi đáng kể độc tính trên tim mạch so với Trastuzumab đơn thuần. Nghiên cứu của chúng tôi không ghi nhận biến cố tim mạch nặng nào phải trì hoãn hoặc dừng điêuu trị. Kết quả này theo chúng tôi là hợp lý bởi cõ mẫu nghiên cứu không nhiêu (20 bệnh nhân) mà tỉ lệ các biến cố tim mạch nặng (suy tim lâm sàng NYHA III-IV, hoặc thay đổi phân suất tống máu thất trái lớn hơn 10\%) ghi nhận được trong thời gian điều trị của phác đồ có Trastuzumab và Pertuzumab thường thấp (tỉ lệ này trong nghiên cứu APHINITY là $0,6 \%){ }^{9}$

\section{KẾT LUẬN}

Điều trị bổ trợ trước ung thư vú có HER2-neu dương tính bằng phác đồ hóa chất kết hợp Pertuzumab và Trastuzumab có tỉ lệ đáp ứng cao, dung nạp tốt.

\section{TÀI LIỆU THAM KHẢO}

1. Sung $H$, Ferlay J, Siegel $R L$, et al. Global Cancer Statistics 2020: GLOBOCAN Estimates of Incidence and Mortality Worldwide for 36 Cancers in 185 Countries. CA Cancer J Clin. 2021;71(3):209-249. doi:10.3322/caac.21660

2. Chumsri $S$, Li $Z$, Serie DJ, et al. Incidence of Late Relapses in Patients With HER2-Positive Breast Cancer Receiving Adjuvant Trastuzumab: Combined Analysis of NCCTG N9831 (Alliance) and NRG Oncology/NSABP B-31. J Clin Oncol Off J Am Soc Clin Oncol. 2019;37(35):3425-3435. doi:10.1200/JCO.19.00443

3. Metzger-Filho 0 , Winer EP, Krop I Pertuzumab: optimizing HER2 blockade. Clin Cancer Res Off J Am Assoc Cancer Res. 2013;19 (20): 55525556. doi:10.1158/1078-0432.CCR-13-0518

4. Gianni L, Pienkowski T, Im Y-H, et al. Efficacy and safety of neoadjuvant pertuzumab and trastuzumab in women with locally advanced, inflammatory, or early HER2-positive breast cancer (NeoSphere): a randomisedmulticentre, openlabel, phase 2 trial. Lancet Oncol. 2012;13(1):2532. doi:10.1016/S1470-2045(11)70336-9

5. Schneeweiss $A$, Chia $S$, Hickish $T$, et al. Pertuzumab plus trastuzumab in combination with standard neoadjuvant anthracycline-containing and anthracycline-free chemotherapy regimens in patients with HER2-positive early breast cancer: a randomized phase II cardiac safety study (TRYPHAENA). Ann Oncol Off J Eur Soc Med Oncol. 2013;24(9):2278-2284. doi:10.1093/annonc/mdt182

6. Phung HT, Nguyen HT, Nguyen TV, Nguyen TV, Dinh LAT, Nguyen CV. Pathological Complete Response with Neoadjuvant Trastuzumab Combined with Chemotherapy in HER2 Positive Breast Cancer: A Single Institution Retrospective Analysis from Vietnam. Breast Cancer Dove Med Press. 2020;12:117-122. doi:10.2147/BCTT.S268369

7. Untch M, Fasching PA, Konecny GE, et al. Pathologic complete response after neoadjuvant chemotherapy plus trastuzumab predicts favorable survival in human epidermal growth factor receptor 
2-overexpressing breast cancer: results from the TECHNO trial of the AGO and GBG study groups. J Clin Oncol Off J Am Soc Clin Oncol. 2011;29(25):3351-3357. doi:10.1200/JCO.2010.31.4930

8. Untch M, Rezai M, Loibl S, et al. Neoadjuvant treatment with trastuzumab in HER2-positive breast cancer: results from the GeparQuattro study. J Clin Oncol Off J Am Soc Clin Oncol. 2010;28(12):2024-2031. doi:10.1200/JCO.2009.23.8451

9. Adjuvant Pertuzumab and Trastuzumab in Early HER2-Positive Breast Cancer | NEJM. Accessed June 11, 2021. https://www. nejm.org/doi/full/10.1056/nejmoa1703643

\section{ĐẶC ĐIỂM LÂM SÀNG VÀ NỒNG ĐộC ĐộC CHẤT HUYẾT THANH CỦA BỂNH NHÂN NGộ ĐộC CẤP HÓA CHẤT DIÊTT CHUộT BROMADIOLON VÀ FLOCOUMAFEN}

\section{TÓM TẮT}

Mục tiêu: Mô tả đặc điểm lâm sàng và nồng độ độc chất huyết thanh của bệnh nhân ngộ độc hóa chất diệt chuột kháng vitamin $K$ tác dụng kéo dài bromadiolon và flocoumafen tại Trung tâm Chống độc Bệnh viện Bạch Mai. Phương pháp: Nghiên cứu mô tả tiến cứu trên 37 bệnh nhân ngộ độc cấp bromadiolon/flocoumafen điều trị tại Trung tâm chống độc Bệnh viện Bạch Mai từ tháng 6/2020 đến tháng 6/2021. Kết quả: Trong số bệnh nhân nghiên cứu, nam chiếm tỷ lệ $62,2 \%$, hầu hết là người lớn, chỉ có 2 bệnh nhi. Nguyền nhân ngộ độc hay gặp nhất là tự tử, tuy nhiên $27 \%$ không rõ nguồn ngộ độc. Triệu chứng lâm sàng thường gặp nhất xuất huyết dưới da (49\%) và các ổ tụ máu trong cơ (35\%). Một số bệnh nhân xuất huyết nă̆ng như xuất huyết não $(2,7 \%)$, tiêu hoá $(27,03 \%)$, tiết niệu $(27,03 \%)$, ổ bụng $(13,51 \%) .3$ BN $(8,11 \%)$ có sốc mất máu. Nồng đồ Bromadiolon và Flocoumafen xu hướng cao hơn ở nhóm bệnh nhân có xuất huyết hoặc INR > 5 (p 0,06), và cao hơn có ý nghĩa ở nhóm có xuất huyết dưới da nặng ( $p 0,012$ và p 0,027 tương ứng ở Bromadiolon và Flocoumafen). Kết luận: nghiên cứu đã cho thấy các đặc điểm lâm sàng và liên quan giữa biểu hiện xuất huyết với nồng độ độc chất huyết thanh của bệnh nhân ngộ độc cấp hóa chất diêtt chuột bromadiolon và flocoumafen.

Tư khóa: bromadiolon, flocoumafen, ngộ độc cấp, đặc điểm lâm sàng, nồng độ độc chất

\section{SUMMARY}

CLINICAL FEATURES AND SERUM

\section{CONCENTRATION OF BROMADIOLONE}

AND FLOCOUMAFEN POISONINGS

Objectives: to describe the clinical characteristics and serum toxin concentrations of patients with acute

\footnotetext{
${ }^{1}$ Trường Đai hoc Y Hà Nôi,

${ }^{2}$ Trung tâm Chống độc

Chịu trách nhiệm chính: Nguyễn Anh Tuấn

Email: nguyenanhtuanbs1980@gmail.com

Ngày nhận bài: 8.9.2021

Ngày phản biện khoa họ: 29.10.2021

Ngày duyệt bài: 10.11.2021
}

\section{Nguyễn Anh Tuấn ${ }^{1,2}$, Phạm Thị Vân Anh', Đặng Thị Xuân ${ }^{2}$, Hà Trần Hưng ${ }^{1,2}$}

poisoning of long-acting anticoagulant rodenticides bromadiolone and flocoumafen at Vietnam Poison Control Center, Bach Mai Hospital. Methods: A prospective observational study included 37 patients with acute poisoning with bromadiolone/flocoumafen treated at the Poison Control Center from June 2020 to June 2021. Results: Among the study patients, male accounted for $62.2 \%$, most of them were adults, there were only 2 pediatric patients. The most common cause of poisoning is suicide, however, $27 \%$ of poisoning sources were unknown. The most common clinical manifestations were subcutaneous hemorrhage $(49 \%)$ and intramuscular hematomas (35\%). Some patients had severe bleeding such as cerebral hemorrhage $(2.7 \%)$, GI $(27.03 \%)$, urinary $(27.03 \%)$ and abdominal hemorrhage (13.51\%). 3 patients $(8.11 \%)$ had hemorrhagic shock. Bromadiolone and Flocoumafen concentrations tended to be higher in the group of patients with bleeding or INR > 5 ( $p 0.06)$, and significantly higher in the group with major subcutaneous bleeding ( $p$ 0.027 respectively in Bromadiolone and Flocoumafen). Conclusion: The study revealed the clinical features and the relationship between the bleeding manifestations and the serum toxin concentrations of patients with acute poisoning of bromadiolone and flocoumafen.

Keywords: bromadiolone, flocoumafen, acute poisoning, clinical features, serum concentration

\section{I. ĐĂT VẤN ĐỀ}

Các hóa chất diệt chuột (HCDC) ngày càng được sử dụng rộng rãi ở cả nông thôn, thành phố với mục đích bảo vệ nông nghiệp, diệt chuột trong các khu công nghiệp, hộ gia đình... Trong đó $\mathrm{HCDC}$ được xứ dụng phố biến nhất là loại kháng vitamin $\mathrm{K}$ tác dụng kéo dài. Do sẵn có, ngộ độc hóa chất diệt chuột cũng là một trong những cấp cứu thường gặp trên thế giới cũng như ở Việt Nam [1].

Trước đây, ngộ độc HCDC loại kháng vitamin $K$ chủ yếu là wafarin. Tuy nhiên, do sự đề kháng wafarin của chuột, $\mathrm{HCDC}$ phổ biến dần thay thế 